\title{
Upaya Meningkatkan Kemampuan Penalaran Matematis Siswa melalui Model Pembelajaran Treffinger pada Materi SPLDV di Kelas VIII-1 SMPN 3 Tangerang Selatan
}

\author{
Lukman El Hakim ${ }^{1, \text { a) }}$, Chindy Listia Utami2,b), Pinta Deniyanti Sampoerno ${ }^{3, c)}$ \\ ${ }^{123}$ Universitas Negeri Jakarta, Rawamangun, Jakarta Timur \\ Email: a) lukman561@gmail.com
}

\begin{abstract}
Abstrak
Penelitian ini merupakan penelitian tindakan kelas (PTK) yang bertujuan untuk meningkatkan kemampuan penalaran matematis siswa melalui model pembelajaran Treffinger dikelas VIII-1 SMPN 3 Tangerang Selatan. Subjek dalam penelitian ini ada lah kelas VIII-1 yang terdiri atas 38 siswa dengan 16 siswa laki-laki dan 22 siswa perempuan. Fokus pengamatan pada dua siswa masing-masing pada kelompok atas, sedang, dan rendah pada materi pembelajaran Sistem Persamaan Linier Dua Variabel (SPLDV). Penelitian ini dilaksanakan dalam 3 siklus. Setiap siklus meliputi tahapan perencanaan, pelaksanaan, analisis, dan refleksi. Untuk memeroleh data kemampuan penalaran matematis siswa menggunakan tes kema mpuan penala ran matematis. Ha sil perolehan nilai untuk setiap subjek pene litian pada siklus I, yaitu SP1 mendapatkan nilai 62,5, SP2 mendapatkan 70,8, SP3 mendapatkan 45,8, SP4 mendapatkan 58,3, SP5 mendapatkan 37,5, dan SP6 mendapatkan 37,5. Pada siklus II nilai tiap SP meningkat, SP1 mendapatkan nilai 75, SP2 mendapatkan 75, SP3 mendapatkan 79,2, SP4 mendapatkan 62,5, SP5 mendapatkan 62,5, dan SP6 mendapatkan 50. Pada siklus III nilai tiap SP juga meningkat, SP1 mendapatkan nilai79,2, SP2 mendapatkan 79,2, SP3 mendapatkan 83,3, SP4 mendapatkan 75, SP5 mendapatkan 75, dan SP6 mendapatkan 70,8. Ketuntasan klasikal subjek penelitian untuk kema mpuan penalaran matematis dalam kategori baik pada siklus III telah mencapai 83,33\%, sehingga dapat disimpulkan bahwa penerapan model pembelajaran Treffinger dapat meningkatkan kemampuan penalaran matematis siswa kelas VIII-1 SMPN 3 Tangerang Selatan pada materi Sistem Persamaan Linier Dua Variabel.
\end{abstract}

Kata kunci: model pembelajaran Treffinger, penalaran matematis, SPLDV.

\section{PENDAHULUAN}

Pembelajaran menjadi unsuryang tidak bisa dihilangkan dalam pendidikan. Meningkatnya kualitas pendidikan sangat bergantung dengan keberhasilan pembe-lajaran. Berbagai bidang studi dalam pembelajaran di sekolah memiliki peranan masing-masing untuk mengembangkan potensi siswa. Salah satu bidang studi yang dimaksud adalah matematika. NCTM menyatakan bahwa standar proses pembelajaran matematika terdiri dari pe-mecahan masalah, penalaran dan pem-buktian, komunikasi, koneksi, dan representasi (Marfi, 2016). Kemampuan penalaran (reasoning) juga merupakan salah satu komponen proses standar dalam Principles and Standards for School Mathematics. Keraf menjelaskan istilah penalaran (reasoning) secara umum sebagai proses berpikir yang berusaha menghubungkan fakta-fakta yang diketahui menuju kepada kesimpulan (Heris dkk, 2017). Aktivitas yang tercakup dalam kegiatan penalaran matematika adalah menarik kesimpulan logis berdasarkan penjelasan yang didapat melalui analisis model, fakta, sifat-sifat, dan hubungan yang tampak pada suatu permasalahan.

Penalaran matematika penting untuk dikuasai siswa agar konsep materi pembelajaran dapat dipahami dengan benar dan dapat diaplikasikan dalam pemecahan masalah yang ada di kehidupan 
sehari-hari. Pentingnya kemampuan penalaran matematis juga dikemukakan oleh Baroody dan Nasoetion bahwa penalaran matematis tidak sekadar membantu individu mengingat fakta, aturan, dan langkah-langkah penyelesaian masalah, tetapi menggunakan keterampilan bernalarnya dalam melakukan pendugaan atas dasar pengalamannya sehingga yang bersangkutan akan memperoleh pemahaman konsep matematika yang saling berkaitan dan belajar secara bermakna atau meaningfull learning (Heris dkk, 2017).

Indikator kemampuan penalaran matematis yang harus dimiliki siswa berdasarkan penjelasan Pedoman Teknis Peraturan Dirjen Dikdasmen Depdiknas Nomor 506/C/Kep/PP/2004 adalah sebagai berikut:

1. mengajukan dugaan,

2. melakukan manipulasi matematika,

3. menarik kesimpulan, menyusun bukti, memberikan alasan atau bukti terhadap kebenaran solusi,

4. menarik kesimpulan dari pernyataan,

5. memeriksa kesahihan suatu argumen,

6. menemukan pola atau sifat dari gejala matematis untuk membuat generalisasi.

Salah satu upaya untuk meningkatkan kemampuan penalaran matematis, yaitu dengan menciptakan pembelajaran yang berbasis proses, sehingga siswa menggali konsep berdasarkan pengalaman mereka sendiri. Ada beberapa model pembelajaran yang mendukung siswa dalam menemukan konsep secara mandiri, antara lain model pembelajaran Quantum, Treffinger, CORE, Creative Problem Solving, dan lain-lain. Penelitian ini memilih model pembelajaran Treffinger untuk meningkatkan kemampuan penalaran matematis siswa karena model Treffinger menekankan pembelajaran pada kematangan pengetahuan yang disertai dengan pengolahan aspek afektif yang sesuai.

Model pembelajaran Treffinger merupakan model pembelajaran yang ber-tumpu pada proses, dimana guru bertindak sebagai fasilitator dan siswa menggali konsep materi berdasarkan pengalamannya, sehingga siswa dapat menganalogi, meng-generalisasi, hingga menyelesaikan permasalahan secara mandiri berdasarkan proses yang ia lalui. Karakteristik paling dominan dari model pembelajaran Treffinger adalah upayanya dalam mengintegrasikan dimensi kognitif dan af ektif siswa untuk mencari arah-arah penyelesaian yang akan ditempuhnya sehingga siswa leluasa untuk beraktivitas dalam menyelesaikan perma-salahan sesuai cara-cara yang ia kehendaki, namun tetap dalam bimbingan dan arahan guru (Sarson, 2006).

Menurut Munandar, langkah-langkah model pembelajaran Treffinger sebagai berikut (Munandar, 2002):

1. Tahap I-Basic Tools

Basic tool atau teknik kreativitas meliputi keterampilan berpikir divergen dan teknik-teknik kreatif. Kegiatan pembelajaran pada tahap I ini terdiri dari: (1) guru memberikan suatu masalah terbuka dengan lebih dari satu penyelesaian, (2) guru membimbing siswa melakukan diskusi untuk menyampaikan gagasan atau idenya sekaligus memberikan penilaian pada masing-masing kelompok.

2. Tahap II - Practice with Process

Practice with process yaitu memberi kesempatan kepada siswa untuk menerapkan keterampilan yang telah dipelajari pada tahap I dalam situasi praktis. Segi pengenalan pada tahap II ini meliputi penerapan, analisis, sintesis, dan penilaian (evaluasi), termasuk juga transformasi dari beraneka produk dan isi, keterampilan metodologis atau penelitian, pemikiran yang melibatkan analogi dan kiasan (metafor). Kegiatan pembelajaran pada tahap II ini terdiri dari: (1) guru membimbing dan mengarahkan siswa untuk berdiskusi dengan memberikan contoh analog, (2) guru meminta siswa membuat contoh dalam kehidupan sehari-hari.

3. Tahap III - Working with Real Problems

Working with real problems yaitu menerapkan keterampilan yang dipelajari pada dua tahap pertama terhadap tan-tangan pada dunia nyata. Kegiatan pembelajaran pada tahap III ini, yaitu: (1) guru memberikan suatu masalah dalam kehidupan sehari-hari, (2) guru mem-bimbing siswa 
membuat pertanyaan serta penyelesaian secara mandiri,(3) guru membimbing siswa menyebutkan lang-kah-langkah dalam menyelesaikan suatu masalah, (4) guru memberikan reward.

Berdasarkan uraian di atas, model pembelajaran Treffinger yang bersif at pengembangan mental dengan menguta-makan proses ini diharapkan mampu meningkatkan kemampuan penalaran matematis siswa kelas VIII-1 SMPN 3 Tangerang Selatan pada materi Sistem Persamaan Linier Dua Variabel (SPLDV).

\section{METODE}

Penelitian ini dilakukan dengan pendekatan kualitatif. Moleong (2014) berpendapat bahwa penelitian kualitatif adalah penelitian yang bermaksud untuk memahami fenomena tentang apa yang dialami oleh subjek penelitian, misalnya perilaku, motivasi, tindakan, dan lain-lain secara keseluruhan dan saling berkaitan dengan cara deskriptif dalam bentuk kata-kata dan bahasa, pada suatu konteks khusus yang alamiah dan dengan memanfaatkan berbagai metode.

Jenis penelitian ini adalah Penelitian Tindakan Kelas (PTK) atau sering disebut dengan Classroom Action Research. PTK memiliki peranan yang penting dalam meningkatkan mutu pembelajaran apabila diimplementasikan dengan baik dan benar. Kusumah dan Dwitagama (2012) mengatakan bahwa PTK adalah penelitian tindakan yang dilaksanakan oleh guru di dalam kelas yang beruparangkaian dari riset dan tindakan guru memecahkan masalah. Pemilihan jenis penelitian ini melihat dari tujuan PTK itu sendiri, yaitu untuk meningkatkan mutu atau kualitas proses dan hasil pembelajaran.

Penelitian ini dilaksanakan di kelas VIII-1 SMP Negeri 3 Tangerang Selatan yang beralamat di Jalan Ir. H. Juanda No. 01, Cempaka Putih, Ciputat Timur, Tangerang Selatan pada semester ganjil tahun ajaran 2018/2019. PTK ini dilakukan sebanyak tiga siklus den gan tahapan masing-masing siklus meliputi: tahap perencanaan, tahap pelaksanaan, tahap analisis, dan tahap refleksi.

Sumber data pada penelitian ini adalah seluruh siswa kelas VIII-1 SMP Negeri 3 Tangerang Selatan semester ganjil tahun ajaran 2018/2019 y ang berjumlah 38 siswa. Pada penelitian ini terdapat enam subjek penelitian yang mewakili siswa pada tingkat atas, menengah, dan bawah berdasarkan hasil UTS dan rekomendasi dari guru matematika kelas VIII-1. Teknik pengumpulan data dilakukan dengan cara mengumpulkan data yang berkaitan dengan subjek penelitian dan ke-giatan pembelajaran di kelas seperti observasi, wawancara terhadap siswa dan guru, hasil tes kemampuan penalaran matematis yang dilakukan di setiap akhir siklus, dan dokumentasi.

Validasi data pada penelitian ini menggunakan teknik triangulasi sumber. Kemudian, dilakukan analisis data untuk mempermudah dalam penarikan kesimpulan sebagai acuan perbaikan tindakan pada siklus berikutnya. Kemampuan penalaran mate-matis siswa dapat dikategorikan sesuai dengan nilai tes kemampuan penalaran matematis siswa di setiap akhir siklus. Berikut ini adalah interpretasi nilai kemampuan penalaran matematis (Arikunto, 2010):

TABEL 1. Kategori Kemampuan Penalaran Matematis

\begin{tabular}{|c|c|}
\hline Kategori & Skor \\
\hline Sangat baik & $81-100$ \\
\hline Baik & $66-80$ \\
\hline Cukup & $56-65$ \\
\hline Kurang & $40-55$ \\
\hline Sangat kurang & $\leq 39$ \\
\hline
\end{tabular}

Indikator keberhasilan pada pene-litian ini meliputi: (1) meningkatnya ke-mampuan penalaran matematis di setiap indikator yang ingin dicapai siswa kelas VIII-1 SMPN 3 Tangerang Selatan dilihat dari nilai rata-rata keenam subjek penelitian untuk setiap indikator kemampuan penalaran matematis mencapai kualifikasi baik dengan persentase 66-80, (2) minimal 80\% dari keenam subjek penelitian mencapai skor 66-80 atau berada dalam kategori baik dalam penilaian kemampuan penalaran matematis sesuai dengan indikator dan pedoman penskoran yang digunakan dalam penelitian ini. 


\section{HASIL DAN PEMBAHASAN}

Kegiatan pembelajaran matematika dengan model pembelaajaran Treffinger dapat meningkatkan kemampuan penalaran matematis siswa pada materi Sistem Persamaan Linier Dua Variabel (SPLDV). Peningkatan ini dapat dilihat selama proses pembelajaran, wawancara, dan hasil tes akhhir siklus yang dilakukan selama tiga siklus. Penerapan model pembelajaran Treffinger dengan pendekatan saintifik untuk meningkatkan kemampuan penalaran mate-matis siswa kelas VIII-1 SMPN3 Tangerang Selatan terdiri dari tiga tahap utama pada model pembelajaran Treffinger dan lima langkah pada kegiatan inti menggunakan pendekatan saintifik. Tiga tahap utama model pembelajaran Treffinger tersebut, yaitu basic tools, practice with process, dan working with real problem.

Pada tahap basic tools, siswa mempelajari materi yang akan dipelajari secara individu melalui sumber belajar yang tersedia, seperti buku paket dan catatan dari guru, setelah itu guru memberikan soal berupa masalah kontekstual yang mem-butuhkan penalaran untuk menjawabnya. Pada tahap ini guru membimbing siswa untuk berdiskusi dalam menemukan berbagai ide yang akan digunakan untuk menyelesaikan masalah. Selanjutnya, memasuki tahap practice with process, guru membimbing siswa untuk memikirkan contoh analaog yang berkaitan dengan materi, kemudian meminta siswa menyampaikannya di hadapan siswa yang lain. Setelah itu, guru kembali meminta siswa memperhatikan masalah berikutnya dan mendiskusikan jawabannya. Pada tahap working with real problem, guru memberikan soal kuis yang berhubungan dengan kehidup an sehari-hari dan dikerjakan secara individu.

Hasil tes akhir siklus keenam SP juga menunjukkan peningkatan dari siklus I hingga siklus III. Berikut adalah nilai tes akhir siklus setiap SP.

TABEL 2. Peningkatan Nilai Kemampuan Penalaran Matematis pada Setiap SP Berdasarkan Tes Akhir Siklus

\begin{tabular}{|c|c|c|c|}
\hline Subjek Penelitian (SP) & Siklus I & Siklus II & Siklus III \\
\hline SP1 & 62,5 & 75 & 79,2 \\
\hline SP2 & 70,8 & 75 & 79,2 \\
\hline SP3 & 45,8 & 79,2 & 83,3 \\
\hline SP4 & 58,3 & 62,5 & 75 \\
\hline SP5 & 37,5 & 62,5 & 75 \\
\hline SP6 & 37,5 & 50 & 70,8 \\
\hline
\end{tabular}

Berdasarkan diagram peningkatan nilai kemampuan penalaran matematis, keenam subjek penelitian pada siklus I yang berada pada kategori baik mencapai $16,67 \%$. Pada siklus II, nilai kemampuan penalaran matematis keenam subjek penelitian mencapai 50\%. Pada siklus III, nilai yang mencapai kategori baik sejumlah $83,33 \%$ dan $16,67 \%$ mencapai kategori sangat baik.

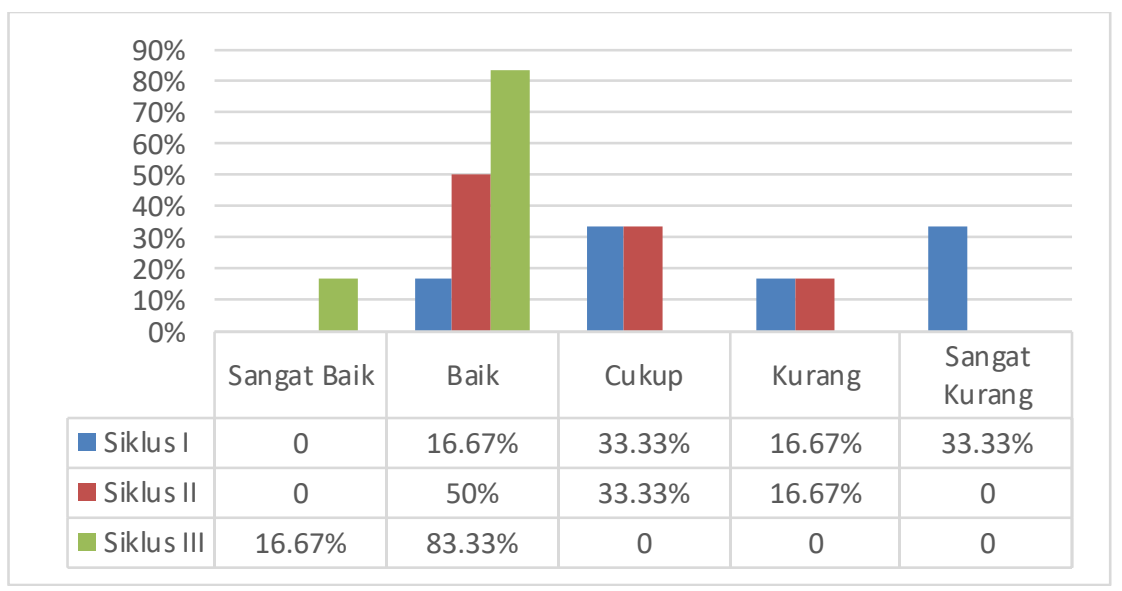

GAMBAR 1. Diagram Peningkatan Persentase Nilai Tes Kemampuan Penalaran Matematis Subjek Penelitian 
Berdasarkan analisis jawaban tes akhir siklus yang dilakukan pada siklus I, siklus II, dan siklus III, kemampuan penalaran matematis keenam subjek penelitian mengalami peningkatan sebagai berikut.

TABEL 3. Persentase Setiap Indikator Kemampuan Penalaran Matematis Keenam Subjek Penelitian

\begin{tabular}{|c|l|c|c|c|}
\hline No & \multicolumn{1}{|c|}{ Indikator } & $\begin{array}{c}\text { Siklus } \\
\text { I }\end{array}$ & $\begin{array}{c}\text { Siklus } \\
\text { II }\end{array}$ & $\begin{array}{c}\text { Siklus } \\
\text { III }\end{array}$ \\
\hline 1 & Mengajukan dugaan & 66,67 & 91,67 & 95,83 \\
\hline 2 & Melakukan manipulasi matematika & 87,5 & 79,16 & 95,83 \\
\hline 3 & $\begin{array}{l}\text { Menarik kesimpulan, menyusun bukti, memberikan alasan } \\
\text { terhadap kebenaran solusi }\end{array}$ & 79,16 & 75 & 79,16 \\
\hline 4 & Menarik kesimpulan dari suatu pernyataan & 41,67 & 45,83 & 75 \\
\hline 5 & Memeriksa kesahihan suatu argumen & 12,5 & 37,5 & 50 \\
\hline 6 & $\begin{array}{l}\text { Menemukan pola atau sifat dari gejala matematis untuk } \\
\text { membuat generalisasi }\end{array}$ & 25 & 75 & 66,67 \\
\hline
\end{tabular}

Pada siklus I, indikator yang mencapai kategori baik atau berada dalamrentang 66-80persen hanya mengajukan dugaan, melakukan manipulasi matematika, dan menarik kesimpulan, menyusun bukti, memberikan alasan terhadap kebenaran solusi. Pada siklus II indikator yang mencapai kategori baik bertambah, yaitu mengajukan dugaan, melakukan manipulasi matematika, menarik kesimpulan, menyusun bukti, memberikan alasan terhadap kebenaran solusi, dan menemukan pola atau sifat dari gejala matematis untuk membuat generalisasi. Pada siklus III, indikator yang mencapai kategori baik bertambah satu indikator dari siklus sebelumnya, yaitu menarik kesimpulan dari suatu pernyataan.

Berdasarkan hal tersebut, dapat dikatakan bahwa pembelajaran matematika melalui model pembelajaran Treffinger sebagai upaya meningkatkan kemampuan penalaran matematis siswa mengalami keberhasilan dalam penerapannya pada penelitian ini.

\section{PENUTUP}

\section{Kesimpulan}

Berdasarkan penelitian upaya meningkatkan kemampuan penalaran matematis melalui model pembelajaran Treffinger pada materi SPLDV di kelas VIII-1 SMP Negeri 3 Tangerang Selatan diperoleh kesimpulan sebagai berikut:

1. Pembelajaran matematika dengan menggunakan model Treffinger dapat meningkatkan kemampuan penalaran matematis subjek penelitian di kelas VIII-1. Hal tersebut dapat dilihat dari rata-rata nilai kemampuan penalaran matematis pada setiap indik ator berada pada kategori baik atau dalam rentang persentase 66-80. Semula hanya tiga indikator yang mencapai kualifikasi baik, yaitu mengajukan dugaan, melakukan manipulasi matematika, dan menarik kesimpulan, menyusun bukti, memberikan alasan terhadap kebenaran solusi. Pada siklus III terdapat lima indikator yang mencapai kualifikasi baik, yaitu (1) mengajukan dugaan, melakukan manipulasi matematika, (2) menarik kesimpulan, (3) menyusun bukti, memberikan alasan terhadap kebenaran solusi, (4) menarik kesimpulan dari suatu pernyataan, (5) menemukan pola atau sif at dari gejala matematis untuk membuat generalisasi.

2. Pembelajaran matematika dengan menggunakan model Treffinger dapat meningkatkan kemampuan penalaran matematis subjek penelitian di kelas VIII-1. Hal tersebut dapat dilihat dari jumlah subjek penelitian yang memperoleh nilai tes kemampuan penalaran matematis mencapai kategori baik, yaitu dalam interval nilai 66-80, semula subjek penelitian yang mencapai kategori tersebut hanya $16,67 \%$, namun di siklus akhir meningkat menjadi $83,33 \%$ subjek penelitian yang mendapat nilai dengan kategori baik ditambah dengan $16,67 \%$ pada kategori sangat baik. 


\section{Saran}

Berdasarkan hasil penelitian, analisis, dan pembahasan yang telah diuraikan, saran-saran yang berkaitan dengan pembelajaran matematika melalui model pembelajaran Treffinger diharapkan dapat bermanfaat serta menjadi bahan pertimbangan pada penelitian selanjutnya yang disimpulkan sebagai berikut:

1. Model pembelajaran Treffinger dapat menjadi sebuah alternatif perbaikan pembelajaran dalam rangka meningkatkan kemampuan penalaran matematis di tingkat sekolah menengah pertama.

2. Untuk mengoptimalkan penggunaan model pembelajaran Treffinger dalam penelitian, sebaiknya guru memperhatikan beberapa hal sebagai berikut:

a. Bahan ajar yang digunakan selama pembelajaran harus dirancang sesuai dengan tujuan yang hendak dicapai, sehingga proses pembelajaran matematika dapat meningkatkan kemampuan penalaran matematis siswa.

b. Pembagian setiap tahap pembelajaran, yaitu basic tools, practice with process, dan working with real problem harus disesuaikan dengan tingkat kesukaran masalah dan kemampuan siswa agar dalam pelaksanaannya tidak kekurangan atau kelebihan waktu.

Estimasi waktu dalam pelaksanaan kegiatan pembelajaran harus diperh atikan dan dialokasikan secara tepat agar pembelajaran menjadi efektif.

\section{REFERENSI}

Adinawan, Cholik M. Matematika 2A untuk SMP/MTs Kelas VIII. Jakarta: Erlangga, 2017.

Arikunto, Suharsimi, dkk. Penelitian Tindakan Kelas. Jakarta: Bumi Aksara, 2012.

Arikunto, Suharsimi. Prosedur Penelitian Suatu Pendekatan Praktik. Jakarta: Rineka Cipta, 2010.

Ario, Marfi. “Analisis Kemampuan Penalaran Matematis Siwa SMK Setelah Mengikuti Pembelajaran

Berbasis Masalah.” Jurnal Ilmiah Edu Research Vol. 5 No. 2, 2016.

Budhi, Wono Setya. Buku Penilaian Autentik Matematika untuk SMP/MTs Kelas VIII. Bandung: Erlangga, 2015.

Denzin dan Lincoln. Handbook of Qualitative Research. Yogyakarta: Pustaka Pelajar, 2009.

Depdiknas. Permendiknas No. 22 Tahun 2006. Jakarta: Depdiknas, 2006.

Hakim, Lukman El. "Profil Proses Berpikir Siswa SMP dalam Menyelesaikan Masalah Matematika

Ditinjau dari Perbedaan Tingkat Kecerdasan Emosi dan Gender." Disertasi. Surabaya: Universitas Negeri Surabaya, 2014.

Hamsiah, Masjudin, dan Ade Kurniawan. "Analisis Kemampuan Penalaran Matematis Siswa SMPN

13 Mataram pada Materi Bangun Ruang." Jurnal Matematika dan Pendidikan Matematika Vol. 5 No. 2, 2017.

Hendriana, Heris, dan Afrilianto. Panduan Bagi Guru Penelitian Tindakan Kelas Suatu Karya Tulis. Bandung: Refika Aditama, 2014.

Hendriana, Heris, Euis Eti Rohaeti, dan Utari Sumarmo. Hard Skills dan Soft Skills Matematika Siswa. Jakarta: Refika Aditama, 2017.

Huda, Miftahul. Model-Model Pengajaran dan Pembelajaran. Yogyakarta: Pustaka Pelajar, 2013.

Institute of Education Science. "Highlights from TIMSS 2011 Mathematics and Science Achievement of U.S. Fourth and Eight Grade Students in an International Context." 2013. Online. https://nces.ed.gov/pubs2013/2013

009_1.pdf. Diakses April 18, 2018.

Keraf, Gorys. Argumentasi dan Narasi. Jakarta: Gramedia Pustaka Utama, 2010.

Kunandar. Langkah Mudah Penelitian Tindakan Kelas Sebagai Pengembangan Profesi Guru. Jakarta: Raja Grafindo Persada, t.thn.

Kusumah, Wijaya, dan Dedi Dwigatama. Mengenal Penelitian Tindakan Kelas. Jakarta: Indeks, 2012. Mikrayanti. "Meningkatkan Kemampuan Penalaran Matematis Melalui Pem-belajaran Berbasis Masalah." Suska Journal of Mathematics Education Vol. 2 No. 2, 2016.

Moleong, Lexy J. Metodologi Penelitian Kualitatif. Bandung: Remaja Rosdakarya, 2014. 
Muklis, Yoga Muhamad dan M. Noor Kholid. "Analisis Deskriptif Soal-Soal dalam Buku Pelajaran Matematika SMP Kelas VIII Semester 1 Ditinjau dari Domain Kognitif TIMSS 2011." Prosiding Seminar Nasional Matematika dan Pendidikan Matematika Universitas Negeri Yogyakarta, 2015.

Munandar, Utami. Kreativitas dan Keberbakatan. Jakarta: PT Gramedia Pustaka Utama, 2002.

NCTM (National Council of Teachers of Mathematics). Principles and Standards for School Mathematics. Virginia: NCTM, 2000.

Nisa, Titin Faridatun. "Pembelajaran Matematika dengan Setting Model Treffinger untuk Mengembangkan Kreativitas Siswa.” Jurnal Pedagogia Vol. 1 No. 1, 2011.

Pomalato, Sarson W. Dj. "Mengembangkan Kreativitas Siswa dalam Pembelajaran Matematika Melalui Pendekatan Model Treffinger." Mimbar Pendidikan No. 1/XXV/2006, 2006.

Rahman, Abdur, dkk. Buku Siswa Kelas 8 Matematika Semester 1. Jakarta: Pusat Kurikulum dan Perbukuan, Balitbang, Kemendikbud, 2017.

Retnowati, Dwi, dan Budi Murtiyasa. "Upaya Meningkatkan Pemahaman Konsep dan Disposisi Matematis Menggunakan Model Pembelajaran Treffinger." 2013. Online. http://eprints.ums.ac.id/23174/17/10._Naskah_Publikasi.pdf. Diakses Maret 28, 2018.

Roesdiana, Lessa. "Pembelajaran dengan Pendekatan Metaphorical Thinking untuk Mengembangkan Kemampuan Komunikasi dan Penalaran Matematis Siswa." Jurnal Pendidikan UNSIKA Vol. 4 No. 2, 2016.

Rosnawati, R. "Kemampuan Penalaran Matematika Siswa SMP Indonesia pada TIMSS 2011." Prosiding Seminar Nasional Penelitian, Pendidikan, dan Penerapan MIPA Universitas Negeri Yogyakarta, 2013.

Sani, Ridwan Abdullah dan Sudiran. Penelitian Tindakan Kelas Pengebangan Profesi Guru. Tangerang: Tira Smart, 2017.

Sari, Yuli Ifana, dan Dwi Fauzia Putra. "Pengaruh Model Pembelajaran Treffinger terhadap Kemampuan Berpikir Kritis dan Kreatif Mahasiswa Universitas Kanjuruhan Malang.” Jurnal Pendidikan Geografi Th. 20 No. 2, 2015.

Setiadi, dkk. Kemampuan Matematika Siswa SMP Indonesia Menurut Benchmark Internasional TIMSS 2011. Jakarta: Kemendikbud, 2012.

Shoimin, Aris. 68 Model Pembelajaran Inovatif dalam Kurikulum 2013. Yogyakarta: Arruzz Media, 2014.

Shurter, R. L. dan J. R. Pierce. Critical Thinking. New York: Mc Graw Hill Inc, 1966.

Slavin, Robert E. Psikologi Pendidikan Teori dan Praktik, Edisi Kesembilan Jilid 2. Jakarta: Indeks, 2011.

Sugiyono. Metode Penelitian Pendekatan Kuantitatif, Kualitatif, dan RnD. Bandung: Alfa Beta, 2009.

Sulistiawati. "Analisis Kesulitan Belajar Kemampuan Penalaran Matematis Siswa SMP pada Materi Luas Permukaan dan Volume Limas." Seminar Nasional Pendidikan Matematika, Sains, dan TIK STKIP Surya Universitas Pendidikan Indonesia, 2014.

Sulistiawati, Didi Suryadi, dan Siti Fatimah. "Peningkatan Kemampuan Penalaran Matematis Menggunakan Desain Didaktis Berdasarkan Kesulitan Belajar pada Materi Luas dan Volume Limas." JJPM Vol. 9 No. 1, 2016.

Sumarmo, Utari. "Kemampuan Pemahaman dan Penalaran Matematis Siswa SMA Dikaitkan dengan Kemampuan Penalaran Logis Siswa dan Beberapa Unsur Proses Belajar Mengajar." Disertasi PPS IKIP Bandung, 1987.

Sumarmo, Utari, dan Heris Hendriana. Penilaian Pembelajaran Matematika. Bandung: Refika Aditama, 2014.

Tan, Oon-Seng. Problem-based Learning and Creativity. Singapura: Cengage Learning Asia Pte. Ltd, 2009.

Tinggi, E. Pengertian Matematik. Yogyakarta: Karya, 1972.

Vebrian, Rajab, dkk. "Pengembangan Soal Matematika Tipe TIMSS Menggunakan Konteks Kerajaan Sriwijaya di SMP." Jurnal Didaktik Matematika Vol. 3 No. 2, 2016.

Wardhani, Sri. Analisis SI dan SKL Mata Pelajaran Matematika SMP/MTs untuk Optimalisasi Mata Pelajaran Matematika. Yogyakarta: PPPPTK, 2008. 